\title{
Implementation of Contextual Learning Model Efforts to Improve the Quality of Online Learning of Professional English Students
}

\author{
Yon Rizal, Widya Hestiningtyas, Albet Maydiantoro \\ Faculty of Teacher Training and Education, University of Lampung, Bandar Lampung City, Indonesia
}

\begin{abstract}
During online learning of professional English courses, economic education students of Faculty of Teacher Training and Education, University of Lampung still tend to be passive, so the quality of existing knowledge is considered to be lacking. It is necessary to apply a learning model that can improve the quality of learning. In this study, the model used is the contextual teaching and learning (CTL) model. The contextual teaching and learning (CTL) approach is a learning concept that helps educators where during the learning process they can relate the material being taught to the natural world conditions of students and encourage them to apply it in their lives as family and community members. The research uses classroom action research (CAR) using two cycles. Based on the observations, the level of student participation in cycle two is known to increase the active participation rate of students by $41.94 \%$. While the results of student evaluation scores in cycle two are known to have increased by $38.71 \%$.
\end{abstract}

Keywords - contextual learning, learning quality, online learning.

DOI: $10.18421 /$ SAR44-03

https://doi.org/10.18421/SAR44-03

Corresponding author: Albet Maydiantoro, University of Lampung, Gedong Meneng Raja Basa, Bandar Lampung City 35141, Indonesia.

Email: albet.maydiantoro@fkip.unila.ac.id

Received: 18 November 2021.

Revised: 07 December 2021.

Accepted: 16 December 2021.

Published: 27 December 2021.

(C) 2021 Yon Rizal, Widya Hestiningtyas \& Albet Maydiantoro; published by UIKTEN. This work is licensed under the CC BY-NC 4.0.

The article is published with Open Access at https://www.sarjournal.com

\section{Introduction}

Education is a process in which the function changes students from previously do not have knowledge and abilities to understanding something. Education is one of the efforts made to change human behaviour both individually and in groups to mature humans through teaching and training [1]. Education is included in the essential human needs. Therefore, humans will not be able to live normally without the education process. Education in Indonesia plays a role as a foundation in the ceremony to educate the nation's life.

In 2020 the world experienced an extraordinary event, namely the outbreak of a virus known as coronavirus disease (Covid-19), including Indonesia [2]. This impacts every order in various fields such as health, economy, and education is one of them. Many countries have decided to temporarily close schools and campuses during the Covid-19 pandemic. Each country makes policies to overcome current problems by carrying out social distancing movements, namely social distancing designed to reduce the interaction of people in the broader community [3]. The impact of this policy made the education sector, such as schools and higher education, stop the face-to-face learning process.

In Indonesia, following the Circular of the Minister of Education and Culture Number 4 of 2020 regarding the implementation of education policies in the emergency period of the spread of Coronavirus Disease (Covid-19), the government recommends carrying out the learning process from home through network-based or online learning. Network-based learning is distance learning, which can be defined as a learning process that does not consider the space and time of learning, has an independent nature for the operation of developing students using methods and media in learning activities [4]. The Covid-19 outbreak has made online learning the primary way to carry out learning activities at universities. Largescale online learning for students is not only a test for university education information construction but is 
also a significant opportunity to promote educational reform in the information age [5]. The results of good learning come from a good learning process as well. The learning process is said to be successful if it gets good results, both knowledge and abilities. If the quality of learning undertaken by students is good, it will get good results as well.

Quality can be interpreted in terms of quality or effectiveness. In Hamdani [6], Etzioni states definitively that significance can be expressed as the level of success in achieving its goals or objectives. Kemendikbud [7] says that the things that determine how good the quality of learning is, can be seen from the learning behaviour of lecturers or teacher educators, student learning behaviours and impacts, learning climate, learning materials, learning media and learning outcomes. These things can be applied through learning models, one of which is through contextual teaching and learning models.

The contextual teaching and learning (CTL) approach is a learning concept that helps educators where during the learning process they can relate the material being taught to the natural world conditions of students and encourage students to apply it in their lives as family and community members, Mulyono [8]. So that during the learning process, educators emphasize to students where they are fully involved in connecting the material being taught with real-life situations to encourage them to apply it in real life.

Lotulung, Ibrahim [9] state that the CTL learning strategy is a learning process that aims to help students see the meaning of the academic material they are learning by connecting educational material with the contents of everyday life, namely with the context of personal and social life and culture. So, the CTL learning model is a learning model that provides facilities for student learning activities to find, process and find more concrete learning experiences (related to real-life) through the involvement of students' activities in trying, doing and experiencing for themselves.

Economics Education University of Lampung is a formal educational institution that carries out the learning process. Students receive various courses during the education process that must be taken to fulfil their studies at the Economics education of the University of Lampung. One of the courses that must be taken is Professional English. Professional English course is a course that aims to improve student's English language skills as prospective educators through oral and written practice. However, since the Covid-19 pandemic has spread in Indonesia, learning Professional English courses has been carried out online.

During the online learning process, lecturers as educators experience obstacles in carrying out the learning process, and this is caused by the interactions that occur become more passive so that the quality of learning not optimal. The impact of the lack of quality learning is a common understanding, skills, and learning outcomes of students, so there is a need for a learning model in which students are active in improving performance and skills regarding English courses, namely by using a Contextual Teaching and Learning (CTL) approach learning model.

Why choose to use the CTL learning model? Because the CTL learning model is a learning model that helps lecturers associate the material being taught with real-world situations and encourages students to make connections between their knowledge and its application in their lives as family and community members. Contextual learning has provided the most comprehensive opportunity for students in groups or working together to develop and integrate a problem [10]. So, this CTL learning model aim students relate learning material, in this case, English, to actual conditions. By applying the CTL model, students are expected to be more active in improving their understanding and skills amid the limitations of online learning.

Based on the explanation above, the researchers decided that they would apply a contextual teaching and learning (CTL) model to improve the quality of online learning for professional English courses for students of the Economics Education study program.

\section{Literature Review}

\subsection{Online Learning}

Along with advances in information and communication, technology brings changes and progress in various sectors, especially education. The role of information and communication technology in education provides convenience to educators and also students in the learning process, especially during the COVID-19 pandemic, which is still being felt. The learning process has changed, in the past, direct learning in the classroom. when the pandemic conditions turned into online learning.

In Kuntarto [11], online learning is learning that uses multimedia technology, virtual classes, CD ROMs, video streaming, voice messages, email and telephone conferences, animated online text, and online video streaming.

Meanwhile, Rosenberg in Alimuddin and Nadjib [12], emphasizes that e-learning refers to the use of internet technology to deliver a set of solutions that can enhance knowledge and skills. In addition, online learning is a learning method that uses technology from the internet network, starting from using Whatsapp, Google Classroom, Zoom, or other applications. According to McNamara, Levinstein [13], using online applications trains students' 
independence and activeness. The same thing was expressed by Waryanto [14], that the advantages of the online learning model are that it can be used to convey learning without being limited by space and time, can use various sources that are already available on the internet, and teaching materials are relatively easy to update.

Online learning is implemented by utilizing a distance learning system so that learning and teaching are not carried out face-to-face. According to Lemay, Doleck [15], online education presents a different learning environment from face-to-face or classroom settings. In addition, according to [16], online teaching provides psychological security for students to continue learning during the COVID-19 pandemic. According to Ermayulis [17], a condition is said to be online if it meets several requirements, including (1) being under the direct control of another device, (2) under the direct control of a system, (3) being available for immediate or realtime use, (4) is connected to a system in its operation, (5) is functional and ready to serve.

\subsection{Contextual Teaching and Learning (CTL)}

The learning model is the basis of learning practice resulting from the decline in educational psychology theory and learning theory which is designed based on an analysis of curriculum implementation and its implications at the operational level in the classroom. The learning model can be defined as a conceptual framework that describes a systematic procedure in organizing learning experiences to achieve learning objectives [18]. The learning model refers to the learning approach used, including teaching objectives, stages in learning activities, learning environment, and classroom management. Contextual Teaching and Learning (CTL) is a learning model that emphasizes students' full involvement to find the material being studied and relate it to real-life situations to encourage students to be able to apply it in life [19].

In line with the above opinion, Blanchard Komalasari and Saripudin [20], suggest that contextual learning is a learning and teaching concept that helps educators relate the material being taught to real-world situations and encourages students to connect their knowledge and its application in life as members family and citizen. Contextual learning is a conception that helps educators relate subject content to real-world situations and motivates students to make connections between knowledge and its application in students' lives [21]. Based on some of the definitions of contextual learning above, it can be explained that contextual learning is a learning approach that links the material studied with the real life of everyday students.
According to Sudiman and Saleh [22], the contextual learning approach has seven main components of effective learning, namely:

\section{a. Constructivism}

Constructivism is the CTL approach's thinking (philosophy), namely that knowledge is built by humans step by step. Knowledge is not a set of facts, concepts, or rules that are ready to be memorized. Humans must construct knowledge and give meaning through experience. In the learning process, students build their knowledge through active involvement in the teaching and learning process. Students become the centre of activity, not educators. In this activity, the task of the educator is to facilitate the process by (a) making knowledge meaningful and relevant to students, (b) allowing students to find and apply their ideas, (c) awareness of students to apply their strategies in learning.

\section{b. Find}

Finding is a core part of CTL-based learning activities. The knowledge and skills acquired by students are not the results of remembering a set of facts but the result of discovering themselves. Educators must design activities that refer to finding activities, whatever the material they teach. The steps for finding activities (inquiry): (1) formulating the problem (in any subject); (2) observing or making observations; (3) analyzing and presenting the results in writing, pictures, reports, charts, tables, and other works; (4) communicating or presenting the work to readers, classmates, educators or other audiences.

\section{c. Ask}

Questioning is the primary strategy of CTL-based learning. In productive learning, questioning activities are helpful for (a) digging for information, both administrative and academic; (b) checking students' understanding; (c) generating responses to students; (d) knowing the extent of the curiosity of students; (e) knowing things that students already know; (f) focusing the attention of students on something the educator wants; (g) to generate more questions from students; (h) to refresh students' knowledge.

\section{d. Learning Community}

The Learning Community concept suggests that learning outcomes are obtained from the collaboration with other people. Learning outcomes are obtained from sharing activities between friends, between groups and between those who know and those who do not know. The practice of the learning community in learning is manifested in (a) the formation of small groups; (b) the formation of large groups; (c) bringing experts to class (d) work with the same class; (e) working in groups with the class above it; (f) working with communities. 


\section{e. Modelling}

Modelling means that in learning particular skills or knowledge, there are models that can be imitated. The model can be how to operate something, or the teacher gives an example of how to do something. Silent learning CTL educators are not the only model. The model can be designed by involving students.

\section{f. Reflection}

Reflection on ways of thinking about what has just been learned or thinking backwards about what has been done in the past. Students precipitate what they have just known as a new knowledge structure, enrichment or revision of previous knowledge. Reflection is a response to events, activities or newly received commands.

\section{g. Actual Assessment}

Assessment is the process of collecting various data that can provide an overview of students' learning development. The actual characteristics of the assessment are (a) conducted during and after the learning process takes place; (b) can be used for formative or summative; (c) what is measured is skill and performance, not remembering facts; (d) continuity; (e) integration; (i) can be used as feedback.

\section{Methodology}

\subsection{Types of Research}

The type of research used in this research is class 2 cycle action research using a descriptive approach. CAR is an observation of learning activities in the form of an action deliberately raised [23]. The PTK model applied is the Kemmis \& McTaggart model. This model is a development of the basic concept proposed by Kurt. D Lewin. In this model, the CAR is carried out through 4 stages: planning, implementing actions, observing, and reflecting, where the implementation continues to the following cycles. The number of cycles is very dependent on the problems that need to be solved [24].

\subsection{Population and Sample}

The population used in this study were students of the 2019 Economics Education study program who took Professional English courses with 62 students. While the sample in this study used a saturated model, which means that the entire population in this study was used as the research sample, amounting to 62 students.

\subsection{Data Collection Techniques}

The data collection technique in this study used a questionnaire where this questionnaire was used as a test tool and to assess student responses. Because the Covid-19 pandemic is still ongoing and there is no permit for the face-to-face learning process, the questionnaire used is presented in digital form using Google Forms media which is then distributed to research subjects.

\subsection{Data Source}

This study uses several sources of data to be analyzed. The first data source is from students of Economics Education University of Lampung. The origins of student data were obtained from observations and questionnaire analysis, observations of student activities, and student learning outcomes. The second data source comes from document data. The document data received is the initial data on student learning outcomes before the action is carried out.

\subsection{Data Analysis Techniques}

Quantitative data in the form of students' cognitive learning outcomes during Professional English courses were analyzed using descriptive analysis techniques and will be presented in the form of percentages.

\section{Results}

\subsection{Research Results Cycle 1}

\section{1) Planning stage}

At this stage, the researchers made preparations related to the implementation of professional English learning using the Contextual Teaching and Learning model in the form of an activity plan and determining the steps to solve the problem. This step is an effort to improve the weaknesses in the bold learning activities carried out so far. The planning includes:

a) learning implementation plan by the material to be presented

b) following the flow of the CTL learning model

c) the instruments to be used: student activity observation sheets and preparing questions to measure students' level of understanding

d) providing tools/media and learning resources 


\section{2) Implementation stage}

At the implementation stage of cycle 1, learning begins according to what has been planned. The activity starts with the apperception to recall the previous material that is still there with the material to be studied. The lecturer instructs students to form groups in which each group consists of 4 people. At this stage, the lecturer will manage students' knowledge of the problem, organize, and guide investigations individually or in groups. In detail, the implementation is carried out as follows.

a) ask students to express their knowledge about the material to be taught today,

b) lecturers motivate students in building new knowledge and experiences based on the students' prior knowledge,

c) guide students to express their opinions or related questions,

d) organize students into study groups, and

e) collect appropriate information through observations related to the material and implementation of CAR.

\section{3) Observation}

Based on observations of student participation levels when learning Professional English courses using the CTL learning model in cycle 1, the following results were obtained.

Table 1. Result of observation of participation rate in cycle 1

\begin{tabular}{ccccc}
\hline Score & Letter & Category & Frequency & $\%$ \\
\hline $80-100$ & A & Very High & 5 & $8,06 \%$ \\
$66-79$ & B & High & 10 & $16,13 \%$ \\
$56-65$ & C & Enough & 10 & $16,13 \%$ \\
$40-55$ & D & Less & 37 & $59,68 \%$ \\
\hline
\end{tabular}

Based on the results of observations of student participation rates in cycle 1 , it is known that as many as $75.81 \%$ or as many as 47 students still do not have a good level of participation. Meanwhile, only $16.13 \%$ or as many as ten students and $8.06 \%$ or as many as five students have high and very high participation rates.

Table 2. Results of cycle 1 evaluation values

\begin{tabular}{ccccc}
\hline Score & Letter & Category & Frequency & $\%$ \\
\hline $80-100$ & A & Very High & 7 & $11,29 \%$ \\
$66-79$ & B & High & 8 & $12,90 \%$ \\
$56-65$ & C & Enough & 17 & $27,42 \%$ \\
$40-55$ & D & Less & 30 & $48,39 \%$ \\
\hline
\end{tabular}

Based on the results of student evaluations in cycle 1 , it is known that as many as $75.81 \%$ or as many as 47 students still do not have good evaluation results.
Meanwhile, only $12.90 \%$ or as many as eight students and $11.29 \%$ or as many as seven students had high and very high evaluation results.

\section{4) Reflection}

Student activities in cycle 1 are still not optimal and have not reached the success criteria. This is due to several problems found. The interaction of students with other students and the tutors is still very passive, and students are still reluctant to respond to statements from the tutors and the opinions of their classmates. In addition, quantitatively, student evaluation scores are still not completely good. There are still many students whose scores can still be optimized again. In detail, the problems found include: (a) most students are still not prepared to receive learning, (b) students tend to be passive and reluctant to respond when giving learning topics, (c) active questions have not developed, (d) most students are still reluctant to activate the camera during online learning.

\subsection{Research Results Cycle 2}

1) The planning stage

Cycle 2 is an improvement from the research cycle 1. The planning in cycle two is done based on reflections in cycle 1 . In the planning of cycle 2 , steps will be planned to correct the deficiencies contained in cycle 1. As for improving the quality of learning in cycle 2, researchers develop learning as follows:

Planning in cycle two will be carried out on increasing student participation and assessing student learning evaluation results. In the planning in cycle 2 , steps will be designed to correct the deficiencies in the process I. The planning carried out includes:

a) learning implementation plan following the material to be presented

b) following the flow of the CTL learning model

c) the instruments to be used: student activity observation sheets and preparing questions to measure students' level of understanding

d) providing tools/media and learning resources

2) Implementation stage

The implementation of learning professional English courses in cycle 2 in improving the quality of learning by applying the CTL model refers to the results of the performance of cycle one, which is considered still not optimal. The supporting lecturers try further to increase participation and understanding of Professional English course material at this stage. Students are asked to join groups that have previously been formed. In detail, the implementation at the implementation stage of cycle 2 is as follows. 
a) orienting the group to the problem,

b) managing prior knowledge of the problem,

c) organize and guide individual and group investigations,

d) analyze and find the problem-solving process, and

e) develop and present the work.

During the series of learning processes, students were observed and assessed the level of participation and how well they understood the material being taught today.

\section{3) Observation}

Based on observations of student participation levels when learning Professional English courses using the CTL learning model in cycle 2 , it is obtained:

Table 3. Result of observation of participation rate in cycle 2

\begin{tabular}{ccccc}
\hline Score & Letter & Category & Frequency & $\%$ \\
\hline $80-100$ & A & Very High & 12 & $19,35 \%$ \\
$66-79$ & B & High & 29 & $46,77 \%$ \\
$56-65$ & C & Enough & 14 & $22,58 \%$ \\
$40-55$ & D & Less & 7 & $11,29 \%$ \\
\hline
\end{tabular}

Based on the observations of student participation rates in cycle 2, it is known that as many as $33.87 \%$ or as many as 21 students still have a reasonable participation rate. This indicates an increase in active participation from students as evidenced by as many as $46.77 \%$ or as many as 29 students and $19.35 \%$ or as many as 12 students having high and very high participation rates. Based on this explanation, it is known that there was an increase in active student participation by $41.94 \%$.

Table 4. Results of cycle 2 evaluation

\begin{tabular}{ccccc}
\hline Score & Letter & Category & Frequency & $\%$ \\
\hline $80-100$ & A & Very High & 13 & $20,97 \%$ \\
$66-79$ & B & High & 26 & $41,94 \%$ \\
$56-65$ & C & Enough & 8 & $12,90 \%$ \\
$40-55$ & D & Less & 15 & $24,19 \%$ \\
\hline
\end{tabular}

Based on the results of student evaluations in cycle 2 , it is known that as many as $35.09 \%$ or as many as 23 students still do not have good evaluation results. Meanwhile, as many as $41.94 \%$ or as many as 26 students and $20.97 \%$ or as many as 13 students experienced an increase in evaluation scores at high and very high levels. Based on this explanation, it is known that there has been an increase in active student participation by $38.71 \%$.

\section{4) Reflection}

Based on the implementation of class actions in cycle 2, the expected results are suitable. Student activities and evaluation results have increased and can be declared victorious. The level of student participation is excellent, and the effects of student evaluations are very high. This shows that researchers have been able to apply the CTL learning model well. Students have also accepted the application of the CTL approach, which is indicated by an increase in the level of participation and the value of the evaluation results. The general picture in cycle 2 is (a) students prepare themselves to receive learning materials, (b) students are active in participating in learning enthusiastically, most students have activated their cameras during learning, although there are still some students who have not activated the camera., they remain active during learning by responding to every statement made when the bold learning takes place.

\section{Discussion}

The Contextual Teaching and Learning (CTL) learning model is proven to improve the quality of learning for economic education students in Professional English courses. The CTL learning model itself is a learning system that produces meaning by connecting academic content with the context of students' daily lives. Learning in the context of CTL, students are not just listening and taking notes but are part of the process of providing hands-on experience. Through direct experience, it is hoped that student development will occur as a whole (cognitive, affective and psychomotor aspects of children can develop in a balanced way) [19].

The results of the study, if in theory are still relevant, according to Sagala [25], learning outcomes are influenced by several factors, both internal and external. The application of the Contextual Teaching and Learning (CTL) model is a learning concept that helps link the material being taught with students' real-world situations and encourages making connections between knowledge that are applied to its application in life. The CTL learning method includes factors outside of the learner's self that affects the quality of student learning.

The CTL learning model can increase student participation from being passive to being more active and able to increase evaluation scores. Students as learners can actively participate in improving English learning materials in everyday life and absorb the material taught well so that the learning experience is also good. However, the CTL learning model immediately improves the quality of learning. Dewi and Primayana [10] state that how well the teacher's teaching ability influences the application of the CTL. The ability to support lecturers has a vital role in every learning process. By having adequate skills, lecturers can design and implement learning models well to increase the quality of courageous learning.

Good quality of learning comes from a good learning process as well. Trigwell and Prosser [26], 
state that improving the quality of learning outcomes can result from establishing an academic environment that encourages deep learning. This means not only in terms of educational expansion but also the learning environment. The environment felt by the student is the environment during the learning process, namely when providing helpful feedback, clarifying goals, criteria and in general what students expect, showing relevant material and trying to create, creating opportunities to ask questions and time to understand each other, good at explaining things, understanding students and providing opportunities for students to decide what and how they learn.

The learning process will take place well if there is a well-established educative interaction between lecturers and students. Not only that, the elements of learning such as the learning behaviour of lecturers or teacher educators, student learning behaviours and impacts, learning climate, learning materials, learning media, and learning outcomes can synergize well with each other through a well-organized learning model. Lecturers, as the main element in the learning process, will try to create conducive conditions. During the bold learning process, the lecturer has been active and has chosen the suitable learning model according to the material to be delivered so that the learning objectives can be achieved optimally. The better the learning process that occurs, the quality of learning will also increase.

\section{Conclusion}

Based on the results of the research that has been carried out, it can be said that the application of the Contextual Teaching and Learning model in the learning of Professional English for Economic Education Students at the University of Lampung can improve the quality of knowledge, both from the level of participation and learning interaction, as well as the results of quizzes and group assignments. In cycle 1 , there are several shortcomings, so that it is necessary to make improvements in cycle 2 , as for what is done by providing intensive guidance, providing opportunities for students to be active by giving praise or awards.

\section{Suggestions}

Through this research, it is hoped that all educators can use more varied and interactive learning models such as the CTL learning model to create an energetic and fun learning atmosphere for students to achieve learning goals. For further researchers, it is expected to conduct are conducting a more in-depth study of the application of the CTL model and developing it further so that it can be better in increasing student learning participation.

\section{References}

[1]. Sugihartono, F. K., Harahap, F., Setiawati, F. A., \& Nurhayati, S. R. (2007). Psikologi Pendidikan. Yogyakarta.

[2]. Maydiantoro, A., Winatha, I. K., Riadi, B., Hidayatullah, R., Putrawan, G. E., \& Dzakiria, H. (2020). Education Institutions during COVID-19 Crisis: Students' Perception of the Situation. Universal Journal of Educational Research, 8(12), 6445-6463.

[3]. Wilder-Smith, A., \& Freedman, D. O. (2020). Isolation, quarantine, social distancing and community containment: pivotal role for old-style public health measures in the novel coronavirus (2019-nCoV) outbreak. Journal of travel medicine.

[4]. Kör, H., Aksoy, H., \& Erbay, H. (2014). Comparison of the Proficiency Level of the Course Materials (Animations, Videos, Simulations, E-books) Used in Distance Education. Procedia-Social and Behavioral Sciences, 141, 854-860.

[5]. Li, J., Qin, C., \& Zhu, Y. (2021). Online teaching in universities during the Covid-19 epidemic: a study of the situation, effectiveness and countermeasures. Procedia Computer Science, 187, 566-573.

[6]. Hamdani, S. B. M. (2011). Bandung: CV. Pustaka Setia.

[7]. Pendidikan, B. S. N. (2008). Kurikulum Tingkat Satuan Pendidikan Sekolah Dasar Model Silabus Kelas V. Jakarta: Badan Standar nasional.

[8]. Mulyono, M. A. (2012). Strategi Pembelajaran Menuju Efektivitas Pembelajaran di Abad Global, Malang : UIN-Maliki Press.

[9]. Lotulung, C. F., Ibrahim, N., \& Tumurang, H. (2018). Effectiveness of Learning Method Contextual Teaching Learning (CTL) for Increasing Learning Outcomes of Entrepreneurship Education. Turkish Online Journal of Educational TechnologyTOJET, 17(3), 37-46.

[10]. Dewi, P. Y., \& Primayana, K. H. (2019). Effect of learning module with setting contextual teaching and learning to increase the understanding of concepts. International Journal of Education and Learning, 1(1), 19-26.

[11]. Kuntarto, E. (2017). Keefektifan model pembelajaran daring dalam perkuliahan bahasa Indonesia di perguruan tinggi. Journal Indonesian Language Education and Literature, 3(1).

[12]. Alimuddin, A., \& Nadjib, M. (2016). Intensitas Penggunaan E-learning dalam Menunjang Pembelajaran Mahasiswa Program Sarjana (S1) di Univeristas Hasanuddin. KAREBA: Jurnal Ilmu Komunikasi, 4(4), 387-398.

[13]. McNamara, D. S., Levinstein, I. B., \& Boonthum, C. (2004). iSTART: Interactive strategy training for active reading and thinking. Behavior Research Methods, Instruments, \& Computers, 36(2), 222-233.

[14]. Waryanto, N. H. (2006). Online learning sebagai salah satu inovasi pembelajaran. Pythagoras, 2(1), 1023. 
[15]. John Lemay, D., Doleck, T., \& Bazelais, P. (2021). Transition to online teaching during the COVID-19 pandemic. Interactive Learning Environments, 1-12.

[16]. Wilcha, R. J. (2020). Effectiveness of virtual medical teaching during the COVID-19 crisis: systematic review. JMIR Medical Education, 6(2), e20963.

[17]. Ermayulis, S. (2020). Penerapan Sistem Pembelajaran Daring Dan Luring Di Tengah Pandemi Covid-19. Webpage STIT Al-Kifayah Riau.

[18]. Suprijono, A. (2009). Cooperative learning: teori \& aplikasi PAIKEM. Pustaka Pelajar.

[19]. Maydiantoro, A. (2020). Penggunaan Model Pembelajaran Kooperatif Tipe Teams Games Tournament Upaya Meningkatkan Pemahaman Belajar. Metafora: Education, Social Sciences and Humanities Journal, 1(4), 99-111.

[20]. Komalasari, K., \& Saripudin, D. (2017). ValueBased Interactive Multimedia Development through Integrated Practice for the Formation of Students' Character. Turkish Online Journal of Educational Technology-TOJET, 16(4), 179-186.
[21]. Trianto, S. P., \& Pd, M. (2007). Model Pembelajaran Terpadu dalam Teori dan Praktek. Jakarta: Prestasi Pustaka.

[22]. Sudiman, A., \& Saleh, S. (2019). Motivasi Belajar Siswa Melalui Model Pembelajaran Kontekstual. Jurnal Pendas (Pendidikan Sekolah Dasar), 1(2), 33-38.

[23]. Arikunto, S. (2016). Prosedur Penelitian. In: Rineka Cipta, Jakarta.

[24]. Kusuma, W., \& Dwitagama, D. (2010). Mengenal Penelitian Tindakan Kelas, Jakarta: PT.

[25]. Sagala, S. (2012). Konsep dan Makna Pembelajaran. Bandung: Alfabeta, 2009. Cet. VII.

[26]. Trigwell, K., \& Prosser, M. (1991). Improving the quality of student learning: the influence of learning context and student approaches to learning on learning outcomes. Higher education, 22(3), 251-266. 